\title{
IZLOŽENOST RIZICIMA I TRENDOVI OSIGURANJA U POLJOPRIVREDI SRBIJE
}

\author{
Dragan Miletić ${ }^{1}$, \\ Marko Milojević, \\ Ivica Terzić
}

${ }^{1}$ Fondacija "Centar za mlade talente", Novi Sad, Srbija

2Univerzitet Singidunum, Beograd, Srbija

\begin{abstract}
Apstrakt:
Poljoprivredu karakterišu biološke, ekonomske i socijalne specifičnosti, na osnovu čega je, sa aspekta osiguranja, kompleksnija u odnosu na druge privredne delatnosti. Ovaj rad želi da ukaže na izloženost tržišnom riziku i prirodnim rizicima koje proizvođači imaju u poljoprivrednoj delatnosti i načinima da se ograniči njihovo negativno dejstvo. Nedovoljna uređenost tržišta strateških poljoprivrednih proizvoda u Srbiji uslovljava prepuštenost primarnih proizvođača pritiscima velikih tržišnih igrača-nakupaca i obaranju cena što obeshrabruje dugoročnija ulaganja i stvara tržišnu nestabilnost. Ukazuje se na afirmaciju i neophodnost unapređenja robnih berzi kao terminskih tržišta na kojima bi se razvijali finansijski instrumenti i prateća infrastruktura koja bi doprinela većoj sigurnosti aktera u pogledu tržišnih rizika. Uticaj prirodnih rizika u poljoprivrednoj proizvodnji se ograničava adekvatnim ugovaranjem poljoprivrednog osiguranja. U radu je iskazano stanje $u$ vezi sa osiguranjem od proizvodnih-prirodnih rizika u poljoprivredi i naznačeni su mogući pravci rasta ovog segmenta osiguranja.
\end{abstract}

Ključne reči:

tržišni rizici, robna berza, proizvodni-prirodni rizici, poljoprivredno osiguranje.

\section{UVOD}

Agrarna politika Srbije je postala ključna tema stručne javnosti od momenta dobijanja datuma pregovora o pristupanju Evropskoj uniji (EU). Proces pregovaranja ima preciznu agendu. Na unutrašnjem planu, potrebno je odgovoriti na pitanje kako podići kapacitete srpskog agrara do nivoa potpune adaptibilnosti sa agrarom EU, odnosno zajedničkom agrarnom politikom EU? Odgovor na ovo pitanje se nalazi u samom procesu pregovaranja, ali delom i na domaćem terenu. Neophodno je iskoristiti sopstvene agrarne resurse, makar na nivou evropskog proseka, i obezbediti veću produktivnost i efikasnost u proizvodnji, što je u interesu svih domaćih aktera (i sa strane ponude i sa strane tražnje), i Evropske unije (Jeremić et al., 2015). Navedeno predstavlja neophodan uslov za uspešan završetak ove etape pregovaračkog procesa. Takođe, postavlja se pitanje u kojoj meri će strani investitori biti spremni da ulažu u domaći agrar i da podignu nivo proizvodnje i konkurentnosti do nivoa kada ćemo na evropskom tržištu biti jedan od prepoznatljivih primera dobre agrarne proizvodnje EU (Galetin, 2014).

Poslovanje robne berze i afirmacija sistema skladišta i sistema robnih rezervi u privredi Srbije znači podizanje nivoa pouzdanosti i sigurnosti privrednog i investicionog ambijenta. Na domaćem agro-tržištu prisutna je velika cenovna oscilacija (čak i u razmerama 1:2), što znači da je domaće agro-tržište visokorizično i da kao takvo generiše tržišnu neizvesnost. Kada bi cenovne oscilacije bile na nivou od 10\% do 15\%, smatralo bi se da je to normalno za tržišnu utakmicu u kojoj jedni dobijaju, a drugi gube u skladu sa principima fer tržišta. Međutim, svako ko želi da uloži u pokretanje proizvodnje u domaćem agraru suočen je sa pitanjem isplativosti proizvodnje i gubitka supstanci. U tom smislu, može se konstatovati da domaći agrar posluje bez implementiranih „alata” za upravljanje visokorizičnim tržištem. 
Današnje tržište primarnih poljoprivrednih proizvoda u Srbiji odlikuju sistemske nepravilnosti koje se manifestuju postojanjem: nakupaca, raznih „organizatora proizvodnje”, otkupa poljoprivrednih proizvoda od strane prerađivača na paritetnoj osnovi, itd. Navedene nepravilnosti umanjuju tržišni kapacitet poljoprivrednih proizvođača i generišu strah od nekontrolisanog rasta cena izazvanog netržišnim ponašanjem pojedinih učesnika u trgovanju, dalje monopolizacije tržišta, skupog, a nedovoljno efikasnog sistema zaštite poljoprivredne proizvodnje za pojedine poljoprivredne kulture. Zato je neophodno uvođenje jasnih pravila za ovaj segment robnog tržišta.

\section{TRŽIŠNI RIZICI}

Sistem upravljanja rizicima je proces kojim organizacije metodološki vode računa o svojim aktivnostima, radi postizanja kontinuirane dobiti u svim aspektima svoje delatnosti. Cilj sistema upravljanja rizicima je stvaranje vrednosti i smanjenje posledica rizika. Upravljanje rizikom na tržištu primarnih poljoprivrednih proizvoda u Srbiji podrazumeva postojanje tržišnih učesnika sa strane ponude i sa strane tražnje.

Ponudu čine:

- poljoprivredni proizvođači - pravna lica kao veliki sistemi (objedinjena primarna proizvodnja, prerada i trgovina),

- poljoprivredna gazdinstva - fizička lica kao velika i srednja komercijalna gazdinstva preko 20 ha,

- poljoprivredna gazdinstva - fizička lica kao mala komercijalna gazdinstva do 20 ha i trgovina.

Potražnju čine:

- izvoznici,

- trgovina - domaće tržište,

- prerađivači i tražnja iz sive zone.

Da bi potencijalni ulagači mogli da trguju na Produktnoj berzi a. d. Novi Sad, jedinoj instituciji takvog tipa u Republici Srbiji, potrebno je da se upoznaju sa načinom funkcionisanja ove berze, tj. načinom na koji mogu da trguju predmetom trgovanja, postupkom kliringa, saldiranja i rizicima.

Indeks Produktne berze Novi Sad se naziva „Prodex” i baziran je na cenama kukuruza, pšenice, soje, ječma, suncokretove sačme i ostale robe koja podleže standardizaciji. Za sada, na ovoj berzi ne postoji terminsko trgovanje niti trgovanje izvedenim finansijskim instrumentima na osnovu poljoprivrednih proizvoda, poput fjučersa i opcija. Prostor za dalji razvoj ovog segmenta berzanskog tržišta je ogroman, što je veoma značajno za ulagače, poljoprivredne proizvođače i društvenu zajednicu.

Terminske robne berze omogućavaju zaštitu od rizika putem takozvanih „hedžing operacija”. Hedžing ili zaštita jeste aktivnost na terminskom tržištu koja svakom tržišnom učesniku omogućava smanjenje rizika putem „hedžing operacija”. Da bi berza kao oblik uređenog tržišta mogla da funkcioniše, neophodno je da bude veoma likvidna, da se na tržištu pojavi što veći broj aktera - „trgovaca” koji neće doći da zaštite svoju proizvodnju (jer je nemaju), već da zarade na trgovinskim operacijama. Upravo ti akteri svojim prisustvom omogućavaju da tržište bude uvek likvidno sa velikim „marginskim računima”, što poljoprivednim proizvođačima i prerađivačima omogućava da zaštite određenu cenu koja se potpuno uklapa u kalkulaciju. Domaća proizvodnja polazi od proizvodnih kalkulacija (bilo da su to poljoprivrednici ili prerađivači) kojima ne proračunava gubitak već dovoljnu zaradu. Ovo je moguć i održiv način dugoročnog planiranja proizvodnje, koji predstavlja preduslov za vođenje dugoročne investicione politike.

Na terminskim tržištima učesnici trgovanja koriste efekat leveridža. Dva osnovna motiva nastupapredstavljaju hedžing i špekulativni poslovi. Špekulativni poslovi se obavljaju na fučers tržištima i tržištima opcija.

Fjučersi su ugovori, tj. sporazumi između trgovca (kupac ili prodavac) i berze fjučersa ili njene klirinške korporacije. Trgovac se ugovorom obavezuje da će isporučiti ili prihvatiti isporuku predmeta ugovora, naznačenog kvaliteta pod uslovima isporuke berze na kojoj se kotira. U zavisnosti od vrste tržišnog materijala koji je predmet trgovanja fuučers ugovorima, postoje robni i finansijski fjučersi. Najpoznatije fuučers berze su: Chicago Borad of Trade (СBOT), Chicago Mercantile Exchange (CME), The International Monetary Market (IMM), The New York Futures Exchange, London International Financial Futures Excange (LIFFE) i dr. (Cvetković, 2002, str. 239).

Za razliku od fjučersa, opcije nemaju sve atribute klasičnih ugovora. Naime, svaki ugovor podrazumeva postojanje saglasnosti između dve ugovorne strane, pri čemu i jedna i druga strana imaju prava i obaveze. Međutim, opcije sadrže pravnu moć, koja se ogleda u pravu da se nešto uradi, ali ne i u obavezi činjenja. Opcije možemo definisati kao pravo, ali ne i kao obavezu da se kupi (call) ili proda ( $p$ t) određeni osnovni instrument (aktiva, roba, hartija od vrednosti, itd.), po unapred ugovorenoj ceni (strike-exercise price) određenog dana (expiry date). Cena po kojoj se to pravo stiče, odnosno cena koja se plaća za opciju, naziva se premija (premium). Postoje brojne opcije, među kojima su najpoznatije opcije na akcije, kamatne stope, tržišne indekse, pojedine berzanske robe, itd. (Vasiljević et al., 2001, str. 173-174).

Terminske berze čine preko 90\% robnih berzi u svetu. Produktna berza Novi Sad a.d. je spot berza koja nije zakonski uređena kao terminsko tržište sa svim benefitima koje taj način berzanske trgovine donosi tržišnim učesnicima. Uspostava terminskog robnog tržišta podrazumeva uporište u Zakonu o robnim berzama. Usvajanje podzakonskih akata, uspostavljanje tehničkih, tehnoloških i kadrovskih kapaciteta je neophodno za postojanje takve institucije. Na ovaj način terminska robna berza u Srbiji bi bila u mogućnosti da implementira zakon i edukuje tržište. Takođe, investitorima bi 
se poslala poruka o postojanju transparentnog, fer i sistemski zaštićenog tržišta u Srbiji. U ovakvom ambijentu državne intervente mere bi bile izuzetak, a ne pravilo, što i jeste odlika uređenih i razvijenih tržišta.

\section{PROIZVODNI - PRIRODNI RIZICI}

Zbog vremenskih prilika i bioloških faktora poljoprivreda je delatnost koja je izložena različitim rizicima. Takođe, izražena je volatilnost cena semena, đubriva, useva i životinja (Erić Jović, 2012). Pored društvenih i ekonomskih rizika, na osnovu jedne od mnogobrojnih metodološko-teorijskih podela, i prirodni rizici predstavljaju grupu rizika (Radović, 2016, str. 30).

Ako je reč o osiguranju prirodnih rizika onda se misli na osiguranje biljne proizvodnje i osiguranje životinja. Za osiguranje biljne proizvodnje se često koristi termin „osiguranje useva i plodova". Rizici u biljnoj proizvodnji uslovljeni su nepovoljnim vremenskim prilikama ili elementarnim nepogodama. Rizici u stočarskoj proizvodnji predstavljaju bolesti ili uginuća životinja.

Smatra se da osiguranje poljoprivrede ima važnu ulogu u zaštiti poljoprivrednih proizvođača, s obzirom na to da su troškovi osiguranja izrazito niski u odnosu na njihovo učešće u ukupnim troškovima (1,5\%-2\%).

Poljoprivredna proizvodnja u Republici Srbiji se zasniva na strukturi poseda u kojoj preovlađuju poluodrživa poljoprivredna gazdinstva. Poljoprivredna gazdinstva koja koriste do 2 ha poljoprivrednog zemljišta zastupljena su sa $47 \%$ u strukturi poseda. Poređenja radi, prosečna veličina poljoprivrednog gazdinstva u EU je oko 20 ha. Ova činjenica direktno utiče na konkurentnost poljoprivredne proizvodnje, na prihode i platežnu sposobnost poljoprivrednog gazdinstva, a samim tim i na tražnju na tržištu poljoprivrednog osiguranja u Republici Srbiji. Na nedovoljnu tražnju na tržištu poljoprivrednog osiguranja utiče i slaba udruženost poljoprivrednih proizvođača što onemogućava povoljnije uslove osiguranja.

Značaj osiguranja poljoprivrede se ogleda u pružanju ekonomske zaštite poljoprivrednim proizvođačima od štetnih dejstava i poremećaja do kojih dolazi ostvarenjem rizika obuhvaćenog osiguranjem. U tom smislu, osiguranje poljoprivede je značajan faktor zaštite i unapređenja poljoprivredne proizvodnje. Potencijal poljoprivrednog osiguranja čini ukupna obradiva površina koja obuhvata: oranice, bašte, voćnjake i vinograde. Razliku između ukupnog poljoprivrednog i obradivog zemljišta predstavljaju površine pod livadama i pašnjacima koji se, po pravilu, ne osiguravaju. Procentualno učešće osiguranih površina u periodu od 2006. do 2014. godine u ukupnoj poljoprivrednoj površini Republike Srbije je u proseku iznosilo 6,32\%, a u ukupnoj obradivoj površini Republike Srbije je iznosilo u proseku 9,32\%! Na osnovu ovih podataka možemo zaključiti da je učešće osiguranih površina u ukupno obradivim površinama Republike Srbije izrazito nisko. Neke od razloga za ovakvo stanje smo već naveli. Do značajnijeg porasta procenta osiguranih površina je došlo nakon katastrofalnih poplava koje su u prethodnom periodu pogodile pojedina područja Republike Srbije. Kretanje vremenske serije prikazano je grafikonom 1 .

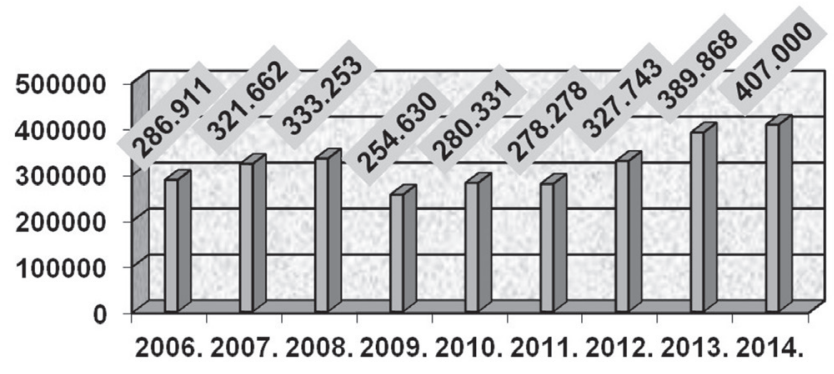

Grafikon 1. Učešće osiguranih površina u ukupnoj poljoprivrednoj i ukupnoj obradivoj površini Republike Srbije u periodu od 2006. do 2014. godine u (000 ha)

Izvor: Radović (2016, str. 188)

Žarković navodi (2015, str. 31) da se osiguranje biljne proizvodnje u Republici Srbiji sprovodi na gotovo neizmenjen način desetinama godina. Polazeći od učestalosti i težine posledica, opasnost od grada, kao osnovni rizik, zauzima prvo mesto. Požar i grom se takođe ubrajaju među osnovne opasnosti. Dopunske opasnosti su oluja, prolećni i jesenji mraz i poplava. Osiguravajuća društva nude i druge mogućnosti obezbeđenja biljne proizvodnje: zaštitu od gubitka semenskog kvaliteta, zaštitu useva i plodova u staklenicima i plastenicima, zasada voćaka i čokota vinove loze u rodu i do stupanja u rod; zaštitu useva i plodova posle žetve, odnosno berbe; zaštitu gubitka kvaliteta, ali ova dopunska osiguranja nemaju veliki značaj.

Stručnjaci smatraju da su mogućnosti tržišta osiguranja biljne proizvodnje u Republici Srbiji veće od aktuelnog nivoa razvijenosti (Radović, 2016, str. 193).

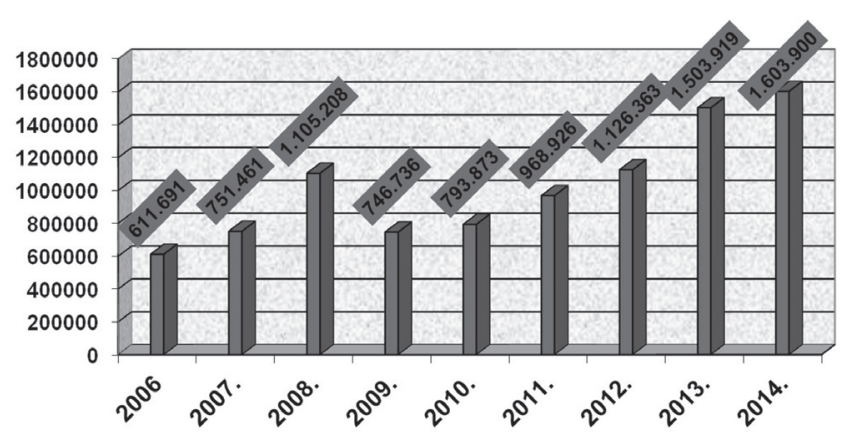

Grafikon 2. Premije osiguranja biljne proizvodnje u (000 din.) Izvor: Radović (2016, str. 189) 
Uvođenje subvencija premija osiguranja nije dovelo do značajnije ekspanzije ove vrste osiguranja, te je očigledno da ova mera nije dovoljna za rast osiguranja biljne proizvodnje (Radović, 2016, str. 193). Pravci razvoja osiguranja biljne proizvodnje u Republici Srbiji, bi trebalo da omoguće zaštitu useva od nestabilnosti zbog klimatskih promena i elementarnih nepogoda (suša, poplava, itd.) koje se potom manifestuju kroz oscilacije prinosa, kvaliteta proizvoda i prodajnih cena.

Žarković (2016, str. 72-74) ističe da se zbog postojanja mnogobrojnih rizika i vrsta životinja, osiguranje životinja javlja u različitim oblicima: osnovno osiguranje, veliki broj dopunskih i posebnih osiguranja, ogledna osiguranja za određene vrste životinja koje se prvi put osiguravaju, odnosno za opasnosti za koje se osiguraniku pokriće daje prvi put. Osiguranje životinja spada u kratkoročna osiguranja koja traju godinu dana ili kraće i obično se vezuju za jedan proizvodni krug. Predmet osiguranja je životinja u celini, a ne njen proizvod ili deo. Osiguravajuće pokriće se može obezbediti samo za životinje određene starosti, koje su zdrave, u dobrom stanju i gajene u prihvatljivim uslovima.

Pokazatelji osiguranja životinja za navedeni raspon godina prikazani su grafikonom 3 .

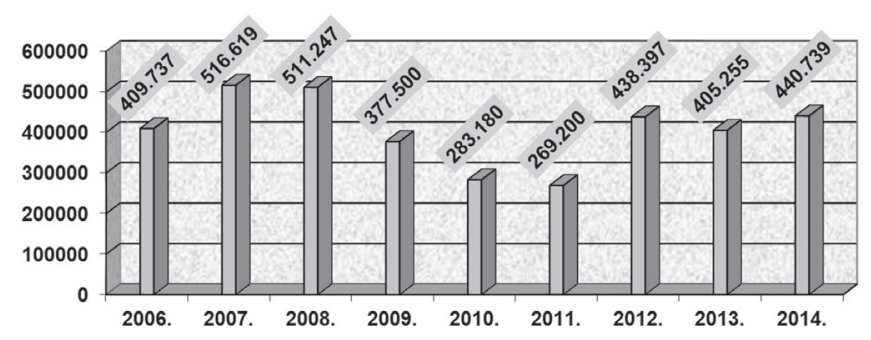

Grafikon 3. Premije osiguranja životinja u (000 din)

Izvor: Radović (2016, str. 197)

Glavni razlozi nedovoljne razvijenosti osiguranja životinja u Republici Srbiji su: relativno niska platežna moć poljoprivrednih proizvođača, nedovoljna informisanost o značaju i potrebi osiguranja životinja i značajan pad obima stočarske proizvodnje u poslednjoj deceniji, dok je ponuda osiguranja kako u biljnoj proizvodnji, tako i u uzgoju životinja dovoljno diversifikovana.

Premija predstavlja cenu osiguranja biljne i stočarske proizvodnje. Uočava se da je osiguranje životinja značajno niže u odnosu na osiguranje biljne proizvodnje. Prosečno učešće premije osiguranja biljne proizvodnje u ukupnoj premiji poljoprivrednog osiguranja Republike Srbije za posmatrani period bilo je 70\%, a premije osiguranja životinja $30 \%$.

Iako u Republici Srbiji ne postoje statistički podaci o broju osiguranih poljoprivrednih gazdinstava, generalna ocena je da je osiguranje poljoprivrede „nedovoljno po obimu, ali i po vrsti zaštite osiguranim rizicima" (Radović, 2016, str. 31). Istraživači mogu doći do približnih podataka, na osnovu broja registrovanih poljoprivrednih gazdinstava koja koriste pravo na regres premije osiguranja. Na posredan način izračunato je da je svega 3,14\% registrovanih poljoprivrednih gazdinstava osigurano. Usvajanjem strategije poljoprivrednog osiguranja država bi omogućila planski razvoj osiguranja poljoprivrede. Pozitivna praksa država u regionu (npr. Republike Hrvatske), koja podrazumeva izradu „karti poljoprivrednih rizika" mogla bi da posluži kao dobar primer. Karte su tehničko sredstvo kojima se utvrđuje verovatnoća nastanka određenih opasnosti i zone rizika pojedinih područja. Karte predstavljaju osnov za utvrđivanje koeficijenta rizika pojedinih područja. Zakonski bi se propisalo tzv. delimično obavezno osiguranje poljoprivrede kao obavezni model osiguranja za korisnike subvencija države u osiguranju poljoprivredne proizvodnje. Prostran (2016) se zalaže za model zakonski obaveznog osiguranja u poljoprivredi: „pre svega za poljoprivredne proizvođače koji koriste subvencije države, jer bi se na taj način izbegle nedoumice šta, kada i kako osigurati. Na taj način se izbegava rizik, a proizvođači se štite od bankrota". U skladu sa proklamovanom državnom strategijom, društva za osiguranje bi bila u obavezi da za proizvođače organizuju obuku iz oblasti osiguranja. Sertifikat bi bio sastavni deo dokumentacije potrebne za dobijanje državne subvencije. Pojedini stručnjaci zagovaraju podizanje procenta regresiranih premija osiguranja sa sadašnjih $40 \%$ na $50 \%$, u skladu sa dobrom evropskom praksom koja ima za cilj povećanje ekonomske zaštite proizvođača. Takođe, predložene mere pominju izbegavanje moralnog rizika kao uslova osiguranja od gubitka prihoda, što podrazumeva obavezu poljoprivrednih subjekata da seju deklarisano seme, koriste mineralna đubriva u potrebnoj količini, kao i hemijska zaštitna sredstva, čime osiguranje dobija puni smisao. Navedene mere bi trebalo da imaju dugoročne pozitivne efekte na razvoj osiguranja i na obezbeđenje stabilnog izvora finansiranja poljoprivrede.

\section{ZAKLJUČAK}

Na osnovu iznetih podataka možemo zaključiti da su mogućnosti razvoja osiguranja zaštite od poljoprivrednih rizika velike kako zbog nedovoljnog stepena dostignutog razvoja ovog segmenta osiguranja u Republici Srbiji, tako i zbog nedovoljne implementacije i osposobljenosti za poslovanje državnih institucija i nedorečenosti zakonske regulative. Rad je ukazao na nužnost uvođenja savremenog terminskog poslovanja u robnom trgovanju strateškim agrarnim proizvodima. Izvesno je da praksa mora naći moduse koji će stimulisati proizvođače da obezbede zaštitu svoje biljne i stočarske proizvodnje, jer je to nužni garant održivosti poslovanja i profitabilnosti. Model delimičnog obaveznog poljoprivrednog osiguranja predstavlja mogući pravac za postizanje višeg stepena zaštite u agrarnoj proizvodnji Republike Srbije. 


\section{LITERATURA}

Cvetković, N. (2002). Strategija investicija preduzeća. Beograd: Institut ekonomskih nauka.

Erić Jović, M. (2012). Osiguranje u poljoprivredi: Značaj i potencijal. Drugi poljoprivredni forum Hrana za Evropu - u susret novoj strategiji agro-privrede Srbije, Panel 4: Osiguranje u poljoprivredi. Subotica: Ekonomski institut, Narodna banka Srbije.

Galetin, Ž. (2014). Uloga tržišta u podizanju konkurentnosti i privlačenju investicija. Konferencija "Agrarna politika Srbije”, NIN Fokus. Beograd: Ministarstvo poljoprivrede, Agencija Tanjug.

Jeremić, Z., Milojević, M., \& Terzić, I. (2015) Business performance of the largest exporters in Serbia during the period 2008-2014. Ekonomika preduzeća, 63(5-6), 293-305.
Prostran, M. (2016). Poljoprivredno osiguranje u Srbiji. Svijet osiguranja, br. 6. Preuzeto 5. oktobra 2016. sa http://svijetosiguranja.hr/sr/clanak/2016/6/poljoprivredno-osiguranje-usrbiji,558,18042.html

Radović, Đ.G. (2016). Poljoprivredno osiguranje kao moguća vrsta obaveznog osiguranja u Republici Srbiji: Doktorska disertacija. Beograd: Univerzitet Džon Nezbit.

Vasiljević, B., Erić, M., \& Šoškić, D. (2001). Finansijsko tržište, regulativa, institucije, instrumenti, analiza. Beograd: Savezna komisija za hartije od vrednosti i finansijsko tržište.

Žarković, N. (2016). Osiguranje poljoprivrede u Srbiji - Nedovoljno razvijeno, a još manje korišćeno, Poljoprivrednikov poljoprivredni kalendar. Novi Sad: Dnevnik- Poljoprivrednik.

Žarković, N. (2015). Stanje u osiguranju biljne proizvodnje u Srbiji: Još uvek bez unapređenja ponude. Časopis Svet osiguranja br. 4.

\section{RISK EXPOSURE AND TRENDS IN SERBIAN AGRICULTURE INSURANCE}

\section{Abstract:}

Agriculture is characterized by biological, economic and social specificities, which, from the insurance viewpoint, make it more complex compared to other economic activities. This paper seeks to highlight the exposure to market risk and natural risks that producers face in agricultural activities and ways to limit their adverse effects. Insufficient market regulations of strategic agricultural produce in Serbia leave the primary producers under the pressure of big market players - middlemen - and cause price reduction, which discourages long-term investments and creates market instability. There is a need for affirmation and the improvement of commodity exchanges as futures markets where financial instruments would be developed along with the supporting infrastructure that would contribute to greater safety of actors regarding market risks. The impact of natural risks in agricultural production is limited by arranging adequate agricultural insurance. The paper presents the current situation of insurance against production-natural risks in agriculture as well as possible future directions for developing this segment of insurance.

\section{Keywords:}

market risks, commodity exchange, production-natural risks, agricultural insurance. 